0040-4039(94)E0388-E

\title{
Generation and Cycloaddition of Heteroatom-Substituted 2-Azanllyl Anions with Alkenes and Alkynes. Synthesis of 1-Pyrrolines and Pyrroles
}

\author{
William H. Pearson* and Erland P. Stevens
}

Depertment of Chemistry. The University of Michigan, Ann Arbor, MI 48109-1055

\begin{abstract}
Abutract: lenidates and thiotmidates 1 bearing an N-(1-tri-n-butylstanyl)alkyl group (e.g-, 7-9) were transmetalated

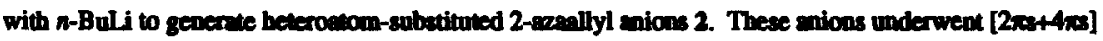
cyckadditions with alkenes wo produce 1-pyrrolines 4 after loss of alkoxide or thiclate. The pyrrolines were further deprotonated in situ with $n-B$ uLi to generate 1-metalbenamines 5 , which could be quenched with water or $\mathrm{CH}_{3} \mathrm{I}$ to produce 1-pyrrolines 4 or 6 . The use of diphenylacetylene in the cycloeddition reanlted in the formation of a pyrrole.
\end{abstract}

We have previously described the synthesis of pyrrolidines by the $[\pi 4 s+\pi 2 s]$ cycloaddition of nonstabilized 2-azaallyl anions with electron-rich alkenes. 1,2 The anions were generated by tin-lithium exchange of 2-azaallyl stannanes. The 2-azaallyl anion method is complementary to azomethine ylide cycloaddition chemistry, since the latter species generally require electron-poor dipolarophiles. ${ }^{3}$ We now wish to describe the generation and cycloaddition chemistry of heteroatom-substituted 2-azaallyl anions 2, which allow access to 1-pyrrolines 4 and 6 (Scheme 1).

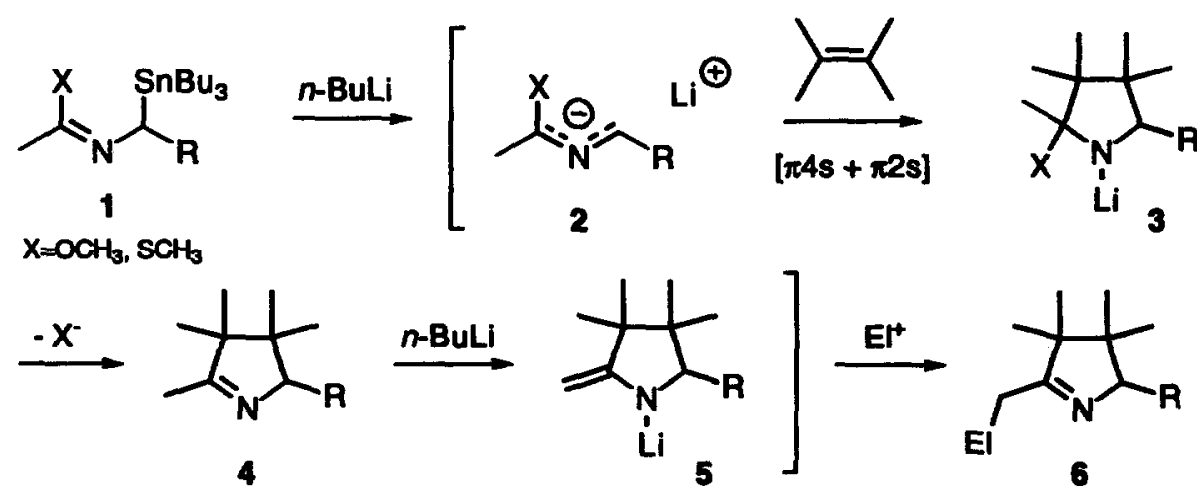

Scheme I. Generation and Cycloaddition of Heteroatom-Substituted 2-Azaallyl Anions 2.

The archetype for the conversion of an alkene to a 1-pyrroline involves the cycloaddition of a mitrile ylide. The cycloaddition of aryl-substituted nitrile ylides ArC $=\mathrm{N}(+) \mathrm{C}(-) \mathrm{HR}$ with electron-poor dipolarophiles has been widely studied. Nitrile ylides without aromatic substitution are rare., 5,6 Heteroatom-substituted azomethine ylides have been used frequently as synthetic equivalents of a nitrile ylides in cyclondditions with electron poor dipolarophiles. ${ }^{7-12}$ The reactions of certain stabilized heteroatom-substituted 2-azaallyl 
anions ${ }^{13,10 c}$ or $\mathrm{N}$-metalloazomethine ylides ${ }^{5}$ with carbonyl compounds or electron-poor alkenes have also been studied. In order to complement the approach to 1-pyrrolines based on heteroatom-substituted 1,3-dipoles, we felt that the higher reactivity of 2-azaallyl anions would allow cycloaddition with less reactive alkenes. We wish to report that non-stabilized heteroatom-substituted 2-azaallyl anions 2 may be generated by tin-lithium exchange on stannyl imidates and thioimidates 1 . These anions undergo cycloadditions with relatively electron-rich alkenes, producing intermediate $\mathbf{N}$-lithiopyrrolidines $\mathbf{3}$, which undergo loss of alkoxide or thiolate to give 1-pyrrolines 4 . Under the basic reaction conditions, 4 is deprotonated to give the metalloenamine 5 . This may be quenched with water to regenerate 4 , or may be alkylated to give a different 1-pyrroline 6.

The tin-substituted imidates and thioimidates $7-9^{14}$ were mixed with various anionophiles (1 equiv.) and added to $n$-BuLi (ca. 5 equiv.) in THF at $-78{ }^{\circ} \mathrm{C}$. After about 30 minutes, workup with aqueous $\mathrm{NH}_{4} \mathrm{Cl}$ and column chromatography $\left(\mathrm{SiO}_{2}\right)$ afforded good to excellent isolated yields of the pyrrolines 10-18 (Table 1). ${ }^{15}$ The use of an acetylenic anionophile provided the pyrrole 19 in modest yield. Particularly noteworthy is the opposite regioselectivity observed in entries 1 and 2 , where the only difference is the heteroatom substituent (oxygen versus sulfur) on the 2-azaallyl anion. The generality of this regioselectivity is currently under investigation. The shift in regioselectivity observed in entries 1 and 3 is also notable. In both cases, the most crowded regioisomer is formed selectively. Complete regiocontrol was observed in the cycloaddition with a vinyl silane (entry 4). Entries 5 and 6 produce the same products 15-18, even though the geometry of the anionophile is different. Normally, we observe stereospecificity with respect to the alkene geometry. 1 However, imines with adjacent aromatic substituents are capable of undergoing imine-enamine tautomerization, ${ }^{16,17}$ which allows scrambling of the stereochemistry of these cycloadducts. The formation of oxidized products, tentatively assigned as 17 and 18 , presumably occurs by air oxidation upon purification. Norbornene and ethyl acrylate were unsuccessful in attempted cycloadditions using 9.

The use of at least 2 equivalents of $n-B u L i$ was found to be necessary because of in situ deprotonation of the initial pyrroline products 4 to form metalloenamines 5 . The presence of 5 was shown by workup of the cycloadditions with methyl iodide, which led to the formation of the 2-ethyl pyrrolines 20 and 21 in good yield (eq. 1,2).<smiles>CCCCC(N=C(C)C)C(C)C</smiles>

9<smiles>CCCCC(N=C(C)OC)C(C)C</smiles>

9

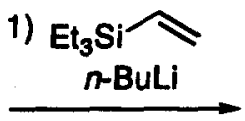

2) $\mathrm{CH}_{3} \mathrm{I}$

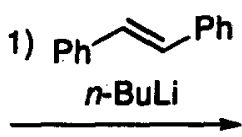

2) $\mathrm{CH}_{3} \mathrm{I}$<smiles>CCC1=N[C@H](C(C)C)[C@H]([SiH2]C)C1</smiles>

20
$65 \%$<smiles>CCC1=NC(C(C)C)C(c2ccccc2)C1c1ccccc1</smiles>

21

In conclusion, the cycloaddition of oxygen- and sulfur-substituted 2-azaallyl anions with alkenes is complementary to 1,3-dipolar methods for making 1-pyrrolines. These anions are far more reactive (i.e., cycloaddition occurs at $-78{ }^{\circ} \mathrm{C}$ ), allowing the use of relatively electron-rich alkenes. Metalloenamines are formed, which are known to be useful synthetic intermediates for further functionalization. Finally, a striking difference in the regioselectivity of oxygen-versus sulfur-substituted 2-azaallyl anions was observed. We are currently exploring this interesting selectivity, as well as nitrogen-substituted 2-azaallyl anions and particularly anions bearing a chiral heteroatom-linked auxiliary for asymmetric cycloadditions. 
Table I. Generation and Cycloaddition of Heteroatom-Substituted 2-Azaallyl Anions

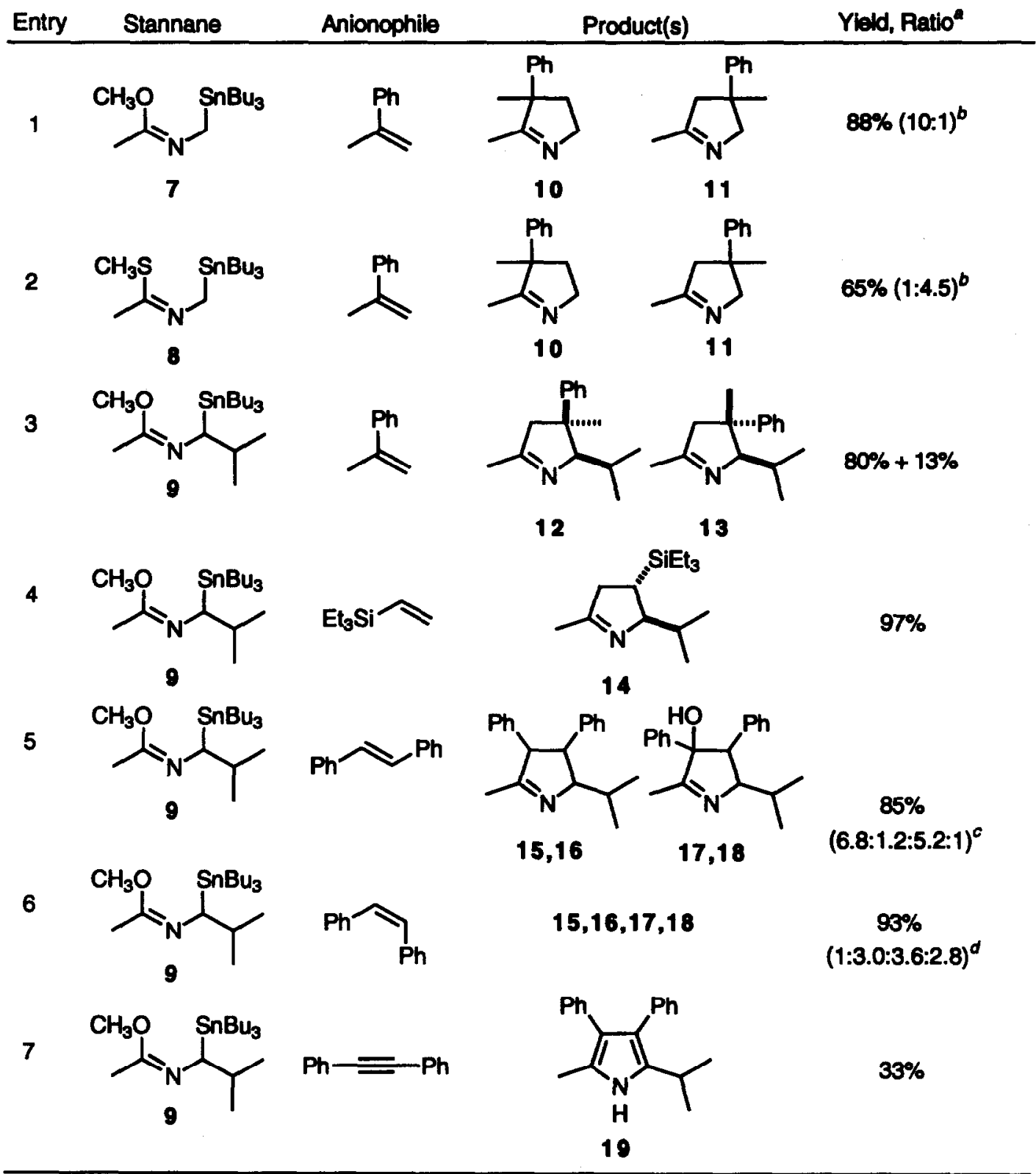

(a) Isolated, chromatographed yields. (b) Isomers not separated. (c) Isolated yield of three chromatographic fractions: $41 \%$ of $15,22 \%$ of a $1: 2$ mixture of 16 and 17 , and $22 \%$ of a $3: 1$ mixture of 17 and 18. (d) Isolated yield of three chromatographic fractions: $9 \%$ of $15,59 \%$ of a $1: 1.2$ mixture of 16 and 17 , and $25 \%$ of 18 . 
Acknowledgment is made to the donors of the Petroleum Research Fund, administered by the American Chemical Society, for support of this research.

\section{NOTES AND REFERENCES}

(1) (a) Pearson, W. H.; Szura, D. P.; Harter, W. G. Tetrahedron Lett 1988, 29, 761-764. (b) Pearson, W. H.; Postich, M. J. J. Org. Chem. 1992, 57, 6354-6357. (c) Pearson, W. H.; Szurn, D. P.; Postich, M. J. J. Am. Chem. Soc. 1992, 114, 1329-1345.

(2) For a review of 2-azaallyl anion chemistry, see: Kauffmann, T. Angew. Chem., Int. Ed. Engl. 1974, 13, 627-639.

(3) (a) Lown, W. J. In 1,3-Dipolar Cycloaddition Chemistry; A. Padwa, Ed.; Wiley: New York, 1984; Vol. 1; pp 663-732. (b) Pearson, W. H. In Studies in Natural Products Chemistry; A. Rahman, Ed.; Elsevier: Amsterdam, 1988; Vol. 1; pp 323-358. (c) Vedejs, E. In Aduances in Cycloaddition; D. P. Curran, Ed.; JAI Press: Greenwich, CT, 1988; Vol. 1; pp 33-51. (d) Tsuge, O.; Kanemasa, S. Adv. Het. Chem. 1989, 45, 231-349.

(4) Hansen, H.-J.; Heimgartner, H. In 1,3-Dipolar Cycloaddition Chemistry; A. Padwa, Ed.; Wiley: New York, 1984; Vol. 1; pp 177-290.

(5) (a) Turro, N. J.; Cha, Y.; Gould, I. R.; Padwa, A.; Gasdaska, J. R.; Tomas, M. J. Org. Chem. 1985, 50, 4415-4417. (b) Padwa, A.; Gasdaska, J. R.; Tomas, M.; Turro, N. J.; Cha, Y.; Gould, I R. J. Am. Chem. Soc. 1986, 108, 6739-6746. (c) Padwa, A.; Gasdaska, J. R.; Haffmanns, G.; Rebello, H. J. Org. Chem. 1987, 52, 1027-1035.

(6) Berree, F.; Marchand, E.; Morel, G. Tetrahedron Lett. 1992, 33, 6155-6158.

(7) (a) Vedejs, E.; Martinez, G. R. J. Am. Chem. Soc. 1980, 102, 7993-7994. (b) Vedejs, E.; West, F. G. J. Org. Chem. 1983, 48, 4773-4774. (c) Vedejs, E.; Larsen, S.; West, F. G. J. Org. Chem. 1985, 50, 2170-2174. (d) Vedejs, E.; West, F. G. Chem Rev. 1986, 86, 941-955.

(8) (a) Padwa, A.; Haffmanns, G.; Tomas, M. Tetrahedron Lett. 1983, 24, 4303-4306. (b) Padwa, A.; Chen, Y.-Y.; Koehler, K. F.; Tomas, M. Bull. Soc. Chem. Belg. 1983, 92, 811-817. (c) Padwa, A.; Haffmanns, G.; Tomas, M. J. Org. Chem. 1984, 49, 3314-3322.

(9) (a) Livinghouse, T.; Smith, R. J. Chem. Soc., Chem. Commun. 1983, 210-211. (b) Smith, R.; Livinghouse. T. J. Org. Chem. 1983, 48, 1554-1555. (c) Smith. R.; Livinghouse, T. Tetrahedron 1985, $41,3559-3568$.

(10) (a) Tsuge, O.; Kanemasa, S.; Matsuda, K. Chem. Lett. 1985, 1411. (b) Tsuge, O.; Kanemasa, S.; Matsuda, K. J. Org. Chem. 1986, 51, 1997-2004. (c) Tsuge, O.; Kanemasa, S.; Yamada, T.; Matsuda, K. J. Org. Chem. 1987, 52, 2523-30.

(11) (a) Alanine, A. I. D.; Fishwick, C. W. G. Tetrahedron Lett. 1989, 30, 4443-4446. (b) Alanine, A. I. D.; Fishwick, C. W. G.; Szantay, C., Jr. Tetrahedron Lett. 1989, 30, 6573-6576.

(12) (a) Kraus, G. A.; Nagy, J. O. Tetrahedron 1985, 41, 3537-3545. (b) Jones, R. C. F.; Nichols, J. R.; Cox, M. T. Tetrahedron Lett. 1990, 31, 2333-2336. (c) Ohno, M.; Komatsu, M.; Miyata, H.; Ohshiro, Y. Tetrahedron Lett. 1991, 32, 5813-5816. (d) Lerestif, J. M.; Bazureau, J. P.; Hamelin, J. Tetrahedron Lett. 1993, 34, 4639-4642.

(13) Tsuge, O.; Kanemasa, S.; Matsuda, K. Chem. Lett 1984, 1827.

(14) Imidate 7: Treatment of $\mathrm{Bu}_{3} \mathrm{SnCH}_{2} \mathrm{I}$ with acetamide (5 equiv.) and $\mathrm{NaH}$ (1 equiv.) in THF/DMF at 0 ${ }^{\circ} \mathrm{C}$ gave $\mathrm{AcNHCH}_{2} \mathrm{SnBu}_{3}(65 \%)$. Heating this material with neat $\mathrm{Me}_{2} \mathrm{SO}_{4}$ (1 equiv.) at $60{ }^{\circ} \mathrm{C}$ gave 7 (61\%, Kugelrohr distillation). Thioimidate 8: Treatment of $\mathrm{ACNHCH}_{2} \mathrm{SnBu}_{3}$ with Lawesson's reagent in THF using ultrasound gave $\mathrm{CH}_{3} \mathrm{C}(\mathrm{S}) \mathrm{NHCH}_{2} \mathrm{SnBu}_{3}$ (49\%), which was alkylated with $\mathrm{Me}_{2} \mathrm{SO}_{4}$ (1 equiv., neat, $23^{\circ} \mathrm{C}$ ) to produce $8(85 \%$, Kugelrohr distillation). Imidate 9: Prepared from AcNHCH(Bt)CHMe (Katritzky, A. R.; Drewniak, M.; Lue, P. J. Org. Chem. 1988, 53, 5854-5856, Bt = benzotriazolyl) by the following sequence: (1) 2 eq. Bu 3 SnLi, THF, $0^{\circ} \mathrm{C}$ (86\%); (2) $\mathrm{Me}_{2} \mathrm{SO}_{4}(1$ equiv.), neat, $60{ }^{\circ} \mathrm{C}$ (74\%, Kugelrohr distillation). See: Pearson, W. H.; Stevens, E. P. Synthesis 1994, 0000 .

(15) The stereochemical assignments of the cycloadducts 12-14 were based on NOE studies.

(16) Burchalter, J. H.; Short, J. H. J. Org. Chem. 1958, 23, 1278-1281.

(17) Pearson, W. H.; Schkeryantz, J. M. J. Org. Chem. 1992, 57, 6783-6789. 